考の発達に行動がついていけないために, この現象が起 つたのではなかろらかと云う意見がのべられて，中島 も, これを十分考慮すると答えてこの問題についての討 議を終了した。

\section{関係把握に関する系統発達的研究}

白井の研究 (213) については, 特別の質問はなかつ たために, 白井の追加発表の形式で, 以下の様な考党が のべられた。

動物と人間の字験の比較が問題になるが, 動物の場合 には，critical な場面に打いて実験を行う事が可能であ るが，人間の場合はそれが一般に不可能である。だから 人間の場合には, motivation の発生のしかたについて 十分な考慮が行われないで, 実験がなされやすい。幼览 を用いる場合には，その母親の協力によつて，空腹時の オヤツを reward として串験を行らのも一案だと考え る。チンパンジーを用いて, この種の実験を行う場合に は, チンパンジーが, 知的感覚を運動感覚によつて, 或 る程度補つて行く傾问がある様に思う。一般に動物実験 と人間実験の場合は, 動物実験に用いた材料をそのまま のパターンで人間に適用し, 法則性を云々するのは避け なければならないと思う。

\section{想起の発達的研究}

杉原らの研究 (214) については, 児玉（日女大）よ り，次の質問があつた。即ち，有意味語と無意味語の 場合, 無意味度の高いものほど想起されやすいといらの は, 有意味語は完全学習に容易に達してしまうが, これ に反して無意味語は完全学習に達するのが比較的におそ いために，かえつて想起されやすくなるのではないかと． いら意見が出された。これに対して, 杉原は, 再生段階 以前の把持段階沉おいて, 有意味語と無意味語の把持率 がぞの位差があるのか，今後検捨してみたいとのべた。
又児玉は, 有意味語の課題をやや難しくしたら plateau になることを，一応さけられはしないか，と云う意見を 们加してこの課題に対する討論を終了した。

\section{描画学習に於ける幼児の飽和と疲労のテスト試案}

加藤の発表 (215) については疲労の問題が, 討議の 中心になつた。すなわち午後 4 時に一応疲労が最高にな る事はみとめるとしても，この時には，疲労の外に心的 飽和の要因が, 同時に介入しているのではないか，この 両者を如何に分離して行くかと云う質問に対して, 加藤 は，両者を正確に分離して考えることは不可能ではなか ろらかと答えた。更に, 疫労の結果を測定するには, 別 の measure を入れて行つたらどらか, 又, 学習の持続 時間に関しては，この場合，同一刺㦸に対する慣れの効 果というものは考慮しなくてもよいのかという意見が出 された。次に白井は，午前中の 3 回のテストの中で, ぞ の時間がテストに最適の時間であると考えるか, テスト を行ら前の作業状態の如何か, 各時間によつて, かなり 異るのではないか, これが異ると, 先行経験の影響がま ちまちになり，その結果に動摇が来るのではなからう か。特に3 回のくりかえしといらことになると，先行経 験の如何を大いに問題にしなければいけないと思う。こ の点については, 午後 4 時のテストの場合も同様であ る。幼児を被験者に用いる場合には一般に云つて，時間 といらょりも生活のリズムの方が大きな影響をもたらす ものと思らという意味の意見がのべられた。これ等に対 して, 加藤は, テストに入る前の生活事情については, 十分に 調査を行ったし， 甚だしく，障がいのある幼児 は，これを除去した旨を答えて，この討論を終了した。

\section{幼児脳波の周波数特性亡知的発達}

伊沢らのこの発表 (216) については，特別の質問も 意見も出なかつた。

(甲斐 直義)

\title{
9. 学習・思考 (4)
}

\section{7 確率学習 (その 4)}

一刺激系列と年令差一

相 田 貞 夫(東京教育大学)

確率学習に和ける刺激列 (2 次確率の高, 低) , と年令 (中 3 と小 3) の効果をみた。予想率は, 小一高は刺激 確率上り高く, 中一高は一致し, 小一低, 中一低は低か つた。確率学習は刺激系列の学習を媒介にしているこ と, 小3は中 3 より, 直前の事態に左右されやすく, 生 起確率の高い刺激を予想しやすい傾向がみられた。

\section{8 不確実場面における児童の判断の 発達的研究}

$$
\begin{gathered}
\text { O出口知子(武庫川病院) } \\
\text { 芳賀 純 (神戸大学) }
\end{gathered}
$$

J. Cohen の追試として 3 種の確率場面を設定し, そ れぞれの場面で小学校 2 年生から高校 2 年生までの児童 生徒がいかに判断し反応するかを比較した。その結果, 小学校 3, 4 年生頃に確率概念が生じていることが確かめ られた。 


\section{9 条件反射における脸波学的研究 (I)}

断続音 (CS) と光 (UCS) の条件づけに 関する後頭葉脳波の分析

○松 田伯 (四国女子短大)

前田文子(広島大学)

パブロフ流の条件づけが脳波の $\alpha$-blocking の現象に あてはまることは，すでに立証されている。本研究は断 続音 (CS) と光 (UCS) を用いた $\boldsymbol{\alpha}$-blocking の条件 づけの過程を後頭葉脳波の瞬時值を分析することにより 明らかにしょうとするもので, 被験者としては犬学生9 名, 小学 3 年生 2 名を用いた基礎的, 予備的研究であ る。

\section{討 論 の 概 要}

第 4 報告が発表取消しになつたので，第 1 報告から第 3 報告までの 3 つの発表と 質疑応答がなされた。以下は その要旨である。

第 1 報告は相田による「確率学習（その 4) 一刺激 系列之年令一」である。確率学習場面で予想率（反 応）を規定する要因の 1 つに一次確率（呈示刺激全体 としての確率) と二次確率 (刺激系列) の関係が考兄 られるが，この報告では二次確率の学習を媒介として 一次確率の学習がなされるといら考えに立つて, 一次 確率の学習におよぼす効果を二次確率（それが高い場 合 $\mathrm{H}$ と低い場合 $\mathrm{L}$ の 2 レベル) と発達差（小学3年 と中学 3 年の 2 レベル) について比較・分析している。 主要な結論は，1）一次確率の学習は中一H 群では prabability matching となつたが，小一L拉よび中一L の群では低く，小-H は高くなつた，2）二次確率の 学習は全群共に二次確率に一致した，3）連構造（たと えば G 2 は GGR……刺激 G が 2 回連続するといら こと）を考虑した分析では，小・中共に $\mathrm{H}$ 群は連の後 にその連に示された刺激を予想する傾向があるが，連の 長さによる効果は小群にはみられず, 中群では negative recency 効果として現われた，そして，4）平均情報量 による分析では，小群の方が中群よりも前試行事象を知 つて次の予想をする場合の uncertainty の度合が小で あり, また小群では予想の当否が, 中群では呈示刺激が より予想の手掛りとなつていること，である。以上か ら, 一次確率と二次確率との関係については, 一次確率 が高い方が低い方よりも学習されやすく, 発達差として は一次確率が高い場合にとくに年令の低い小群において 学習の手掛りとなつたことが明がされた。

【質疑応答〕「確率学習場面での反応（予想）の個人 差について (芳賀)」は「多くの被検者は $50 \%$ の予想
から始めるが，100\%または0\%から始める被検者もあ る。また，一次確率を規定する試行数が小さい場合には 個人差が強くでるようである (相田)」，また，「確率学 習のみられるのは何䪱からか (芳賀)」に対しては「刺 激確率，それを規定する試行数，reward などの条件化 より異なるが，本実験の条件下では 5〜6才でもみら れる。他の種々の場面での研究では 4〜6才でもみられ るとあるが，弁別可能な確率は 5 6 才では60\% 位が限 度のようである(相田)」の応答があつた。

第 2 発表は出口・芳賀による「不確実場面に拈ける 巟童の判断の発達的研究」である。ここでは, 食物, 括 金, 学習の 3 場面で, それぞれ，1つの reward を確 実に鿓らことに対して，1/5 の確率のクジを 1 回だけ引 いて当れば 5 倍の reward を貪う, および, 1/25 の確 率のクジを 1 回だけ引き当れば 25 倍の reward を貫 5（従つてそれぞれの場合の確率は1となる）3選択の いづれを被検者が選ぶか，そしてその理由は何かを，小 学校 2 年から中学校 2 年までについて質問紙法により比 較している。

主要な結果は，1）小 4 頃に選択の傾向が分化すると いら意味で発達上の差が生じてくる，2）選択の理由が 確率の 概念によりなされる比較が小 4 頃から大になつ た，3）小 4 以上の選択の理由は, 確率の概念を理解し た上で，確実だから選択したとか，この程度の確率なら 当るかも知れないといらスリルと考兵て選択するような 分化を示した。

〔婜疑応答〕「インストラクションの方法と確率場面 の定義について（佐久間，九大)」に対しては「確率 3 場面はそれぞれ 全体としての数学的確率は1となる （出口）」という説明がなされた。「Utility と主観確率 に関する報告者の見方について(宮原)」に対しては「こ の研究がイギリスの John Cohen の研究の追試である ことから, exploratory なものであること, および, utility については実際に reward を与える実験的方法 で比較してゆく意図をむつている(芳賀)」の応答があつ た。

第3 報告は松田・前田による「条件反射に打ける脳波 学的研究 I 断続音 (cs) と光 (ucs) の 条件づけに関 する後頭葉脳波の分析」である。脳波研究が Pavlov 流の条件反射研究や発達研究などに貢献するといらこ とから，ここでは基礎的かつ予備的な研究として条件づ けの過程を脳波分析した。実験手続きは shield box 内の被験者（小3 から大学生までを含む）の左後頭部 と左耳に電極を付け，暗室条件で開眼させ，前方 $1 \mathrm{~m}$ のランプとブザーを使用して，0.1 秒間隔で 0.1 秒の長さ 
の音刺激 cs を10 秒間, 15〜20試行与えて順応させ， その後さらに数回与える。次に, cs を10秒与え, 1 秒後に光刺激 ucs 2 秒与える強化を 20 試行扣こな い, その強化試行中に at random に5 回テスト試行 をする。この後 cs のみ提示の消去試行を10回おこな 5。以上の結果を脳波分析により， $\delta_{1}(2 \sim 4 \mathrm{c} / \mathrm{s}), \theta(4 \sim$ $8 \mathrm{c} / \mathrm{s}), \boldsymbol{\alpha}(8 \sim 13 \mathrm{c} / \mathrm{s}), \boldsymbol{\beta}_{1}(13 \sim 20 \mathrm{c} / \mathrm{s})$ 帯域の瞬時値の振 巾の平均を cs 提示の 2 秒間, cs 提示後の 1 秒間, ucs 提示の 1 秒間, ucs を示さない場合の 1 秒間について求 め, cs 提示 2 秒に対する\%に変換して, 各々の比較・ 分析をした。

主要な結果は，1）年-blocking の条件づけは可能で あるが, 不安定かつ変動があるという Albino \& Burnand の結果を裹づける結果が得られた，2) $\delta_{1}, \theta, \alpha$ および $\boldsymbol{\alpha}$ 波のそれぞれで周波帯域の変化があるが，条 件づけが成立したと思われるテスト試行で条件づけ試行 と異なることは， $\boldsymbol{\alpha}$ 帯域で ucs が提示される（実際に は未提示であるが) 時期の後に增大している，3）消去
が完了したと考えられる時期では ucs が提示されるは ずの時期に $\boldsymbol{\alpha}$ 波帯域での増大がみられる，および，4) $\boldsymbol{\alpha}$-blocking の周波数分析の研究で元木沢の結果と $\theta$ 波 の結果が一致しないのは, 本報告では瞬時值分析の結果 を求めたことによるらしい，ということである。

〔質疑応答〕「音の強さと遮蔽の条件，休息を一まと めにとつた理由， $\boldsymbol{\alpha}$-blocking と adaptation の判定基 準, および,瞬時值の振巾の平均を求めた理由は（堅田， 教育大)」および「cs と ucs 時を通じて被検者に開眼 の状態をとらせた理由（氏森,教育大）」に対して「音刺 激は 40〜 50db, そして, 整理の方法については勿論問 題はあるが，一応心理的現象との対応をどのようにあら わすかを考えるために，この整理法をとつた」という説 明がなされた。

以上が，3 報告の概要と質疑応答の要約である。質疑 は確率学習と脳波条件づけに 2 分してなされたが，その 内容は比較的方法論に関するものが多かつた。

（宮原英種）

\section{0. 学 習・思考 (5)}

220 京大 $\mathbf{N X}$ 知能検査報告 (14)

-10年前との成績比較一

○金子㔚栄・倉石精一

党阪良二・梅本堯夫(京都大学)

知能の時代差をみるために小学 5 年生（大都市）飞知 能検査を実施し，それと約 10 年前の同じ地域の結果と を比較した。結果：(1) 空間的下位検査の上梨が著しい。 (2) 他の検査も若干上昇したが，これは現代のテスト慣 れが原因しているように思える。(3) 解答の際における 正確さの增加が 得点上笔の主因をなすものと考兄られ る。

221，222 タキストスコープによる言語近 似系列の認知 (3)

佐 久間 章(九州大学) 岩城正彥・宮原英種(福岡学芸大学)

タキストスュープによる近似英語の瞬間的認知につい て G.A. Miller, 大西等の結果を追試したほか，刺激系 列の確率的構造以外飞認知に及ぼす要因として文字の形 態の差異（アルフアベットの大交字と小文字）扣よび英 語に対する学習経験の差異（大学生と中学生被験者）を 検討した。その結果，近似英語に対する認知は大学生， 中学生共に近似度の上枡に対応して容易になるが，両者
の間には英語学習に対する習熟度の差異から生起する認 知量の差が認められた。大文字と小文字系列では後者の 場合がかなり高い正答率が認められ，英語近似系列の認 知では文字の確率的構造 (近似度) だけでなく，その文 字の形態が 1 つ因子として効果をもつたことが推定さ れた。

\section{3 コトハハの使用頻数及び長さと認知闘 の関係 \\ 一人間に拈ける学習行動の検討（その6) \\ ○河井芳文・杉原一昭(東京教育大学)}

コトバの使用頻数（4段階に分けて）及び，その長さ （文字数 2 字と 4 字）と認知聞の関係をタキストスュー プで調べ次の結果を得た。（）使用頻数の対数と認知間 は直線的関係, (b) 頻数間に有意な認知闒の差, (C) 長 さと使用頻数の間に弱い交互作用が見られ，(d) 長いコ トバは使用頻数の影響を大きく受ける（直線の勾配が大 きい)。

\section{4 テトスの因子構造と Motivation}

\section{織 田 揮 準(名古屋大学)}

動機づけ水準の增大は検查の反応速度を速めるが，能 力に影響を及ぼさないとする従来の仮説が知能検査にど 